\title{
IS FOREIGNNESS A SOURCE OF COMPETITIVE ADVANTAGE IN THE BRAZILIAN PHARMACEUTICAL INDUSTRY?
}

\section{A CONDIÇÃO DE SER EMPRESA ESTRANGEIRA É UMA VANTAGEM COMPETITIVA NO SETOR FARMACÊUTICO BRASILEIRO? UM ESTUDO EXPLORATÓRIO}

\begin{abstract}
During the first decade of the $21^{\text {st }}$ century, the accelerated growth of the pharmaceutical market in Brazil attracted investments from multinational pharmaceutical companies. National companies followed this investment trend, and the industry matured, and competition intensified. However, companies that operate in a foreign, new environment, driven by unfamiliar competitive forces encounter additional costs to operate. Using data from 2011 to 2016, this study employs panel data methodology with fixed effects using a sample of twenty-two pharmaceutical companies, eleven Brazilian subsidiaries of multinationals and eleven national companies, with the objective to investigate whether foreign companies operating in Brazil incur a liability of foreignness (LOF), which refers to these additional operating costs. This study contributes to the literature by evaluating the impact of Liability of Foreignness on working capital and profitability in the pharmaceutical sector. Our findings suggest that MNEs have a competitive disadvantage in inventory management compared to local companies.
\end{abstract}

Key words: liability of foreignness, asset of foreignness, working capital, profitability, pharmaceutical industry.

\section{RESUMO}

Durante a primeira década do século 21 , o crescimento acelerado da indústria farmacêutica no Brasil atraiu investimentos de empresas farmacêuticas multinacionais. As empresas farmacêuticas nacionais seguiram a tendência de investimento, a indústria amadureceu e a competição se intensificou. Entretanto, empresas que operam em países estrangeiros encaram novos ambientes marcados por forças competitivas desconhecidas que geram custos operacionais adicionais. Usando dados de vinte e uma empresas farmacêuticas, onze subsidiárias brasileiras de multinacionais e onze empresas nacionais, de 2011 a 2016, este estudo utiliza a metodologia de dados em painel com efeitos fixos com o objetivo de verificar se há evidências de custo do estrangeiro (liability of foreigness) no Brasil. O estudo contribui com a literatura ao avaliar o impacto do custo do estrangeiro (liability of foreigness) no capital de giro e lucratividade de empresas do setor farmacêutico. Nossos resultados indicam que multinacionais possuem uma desvantagem competitiva na gestão de estoques quando comparadas com empresas locais.

Palavras Chaves: liability of foreignness, asset of foreignness, capital de giro, lucratividade , indústria farmacêutica.

\section{Hsia Hua Sheng}

Professor Associado de finanças na FGVEAESP e Vice-Presidente do Bank of China (Brasil) S.A. Graduado em Economia pela Universidade de São Paulo (FEA - USP) Doutor e Mestre em Administração em Finanças pela FGV - EAESP. Foi Visiting Scholar na NYU Stern School of Business e na Shanghai University of Finance and Economics (SHUFE). Contato: Rua Itapeva, 474, Bela Vista, São Paulo, SP, Brasil, CEP 01332-000. E-mail: hsia.sheng@fgv.br

Ricardo Itapema de Castro Monteiro Graduado em Administração de Empresas pela FGV-EAESP. Pós-graduado em Gestão Estratégica pela ISE/IESE Universidade de Navarra. Mestre em Gestão para Competitividade em Finanças e Controladoria pela FGV - EAESP. Atualmente é CFO da subsidiária brasileira da multinacional farmacêutica alemã Grünenthal. Contato: Rua Francisco Leitão, 675, São Paulo, SP, Brasil, CEP 05414-025 E-mail: ricardo.itapema@gmail.com 


\section{INTRODUCTION}

This article aims to evaluate the existence of the 'Asset and Liability of Foreignness' in the Pharmaceutical industry in Brazil. Assets of Foreignness (AOF) refer to the unique benefits that a multinational subsidiary (MNE) gets when operating in a foreign country (Mallon and Fainshmidt 2015). Liability of Foreignness (LOF), on the other hand, refers to the costs of doing business abroad that result in competitive disadvantages for an MNE subsidiary (Zaheer, 1995).

During the first decade of the $21^{\text {st }}$ century, the number of multinational corporations operating in the Brazilian pharmaceutical market quintupled, reaching $25 \%$ of the total number of companies and $49 \%$ of overall market sales in 2017 (IQVIA, 2017). National companies (NACs) grew and quickly gained market leadership. In the global rankings of major pharmaceutical markets (IQVIA, 2017), the Brazilian market went from the 10th position in 2011 to the 8th in 2016, and it is expected that will reach the $5^{\text {th }}$ position in 2021. Changes in the competitive and regulatory settings that resulted in a market consolidation, introduced a higher pressure on price formation, challenges to the dynamics of portfolio replenishment and difficulties in negotiations with pharmacy chains/wholesalers. Besides, changes in the MNEs product global sourcing strategy brought challenges to its subsidiaries on obtaining products to its markets (Gomes et al, 2014).

MNEs investing in new markets abroad must have specific assets with considerable advantages to confront the disadvantages existent in foreign markets (Caves 1971). In this new competitive and operational environment, pharmaceutical companies had to increase investments in trade credit and inventory to preserve competitiveness. Thus, working capital management became a strategic capability. According to Almeida et al (2014), identifying the main drivers and appropriate levels of working capital became one of the most important subjects for financial officers.

Several studies on the Brazilian market have tested the existence of the AOF or LOF in local industries, but none has targeted the pharmaceutical industry. Building on the findings of Deloof (2003), Lazaridis et al (2006), Gill et al (2010), Enqvist et al (2014) and Bozzeda (2017), this study contributes to the literature by evaluating the existence of asset and or liability of foreignness in the Brazilian pharmaceutical sector. Also, it evaluates the relationship between working capital and profitability in a sample of twenty-two companies (eleven Brazilian subsidiaries of MNEs and eleven national owned companies) from 2011 to 2016.

Using panel data, this study tests four hypotheses to assess whether the foreignness status of MNEs represents a competitive advantage or disadvantage (and therefore an AOF or LOF) in terms of working capital and its core elements (accounts receivable, inventory, accounts payable). Our findings demonstrate the existence of LOF on the relationship between return on assets and inventory, which suggests that inventory levels have a negative impact on the profitability of MNEs operating in the Brazilian pharmaceutical industry. The findings also indicate that the higher the financial debt ratio of MNEs, the lower their profitability.

\section{THEORETICAL FRAMEWORK}

\subsection{Assets and Liability of Foreignness}

Assets of Foreignness (AOF) are those unique benefits that multinationals have when operating abroad and are unavailable to host-country rival companies (Mallon and Fainshmidt 2015). Sethi and Judge (2009) argue that foreignness can sometimes be a source of an advantage because it can include the ownership of unique resources, capabilities, and/or opportunities unavailable to host-country competitors. Goguen and Conolly (2012), for instance, demonstrate that physicians (and patients) in emerging markets usually choose medication produced by multinational enterprises, commercialized under international brands due to their higher perceived quality (Goguen et al, 2012). Dunning (1998) suggests that these advantages are motivated by technological intensity and specific types of organizational skills/assets. Delios et al (2001) concluded that intangible assets, such as patents and trademarks, increase MNEs competitiveness in a host-country. Fagre et al (1982) identified that the magnitude of foreign direct investment to a certain country is a powerful bargaining lever in negotiations with the host-country government.

Alternatively, Hymer $(1960,1976)$ observed that, in contrast to local companies, multinationals face additional costs associated with the unfamiliarity with the local market. Hennart (1982) also suggested that the operation of a business in a foreign country often implies higher costs and expenses. Zaheer and Mosakowski (1997) concluded that multinational subsidiaries (MNEs), frequently come across extra costs driven by the lack of knowledge of the economic environment and its political influences, the distinct treatment from local government in favor of national companies, the reluctance of nationalist buyers to purchase from foreign companies, as well as restrictions imposed by the home government of a company.

Barnard (2010) suggested that LOF can come from firm-specific factors and concluded that the level resources and capabilities available for a subsidiary operation in a foreign market depend on the home and host market development level. Mezias (2002) observed the existence of Liability of foreignness (LOF) at federal and state court levels in different regions of the United States, concluding that foreign subsidiaries operating in the country have a disadvantage in the settlement of labor lawsuits. Likewise, Bhattacharya et al (2007) investigated all types of disputes (antitrust, agreement conflicts, labor disputes, patent violation and product liability) present at the federal courts of the US and concluded that American companies have more of an advantage at federal courts than foreign companies. Gaur et al (2011) suggested that different firms, on the same location, suffer different magnitudes of LOF depending on their level of resources and 
institutional experiences. Eden and Miller (2004) also indicate that institutional differences pose difficulties for MNEs trying to stablish legitimacy in a host-country.

\subsection{Working Capital and ROA}

Working capital (WC) is the flow of funds necessary for a company to operate activities. It includes funds invested in current assets that shortly become cash and current liabilities (short-term obligations). In this sense, efficient working capital management is a vital aspect of financial management practice. Almeida (2010), for instance, analyzed Brazilian listed companies and concluded that an efficient management of working capital is a critical part of the strategy of any company that intends to create value to shareholders. Maximizing profits is another important topic relevant to financial managers (Raheman at al 2007). However, preserving liquidity while maximizing profits can be a challenge. If a company does not prioritize profits, it may not survive. However, if it does not manage its working capital, it may face insolvency or even bankruptcy.

Almazari (2013) argues that companies should not pursue one objective at the expense of the other, because working capital management can affect profitability. Deloof (2003) analyzed 1009 listed Belgian companies and found a significant and negative relationship between profitability and working capital. He also identified a similar result in the relationship between accounts payable and profitability. Gill, Biger, \& Mathur (2010) analyzed eighty-eight American companies listed on NYSE from 2005 to 2007 and found a statistically significant and negative relationship between profitability and accounts receivable position (DSO) and a positive relationship between cash conversion cycle (CCC) and profitability. They concluded that profitability dictates how managers act in terms of managing accounts receivables and therefore companies can create value for their shareholders by reducing the number of days for accounts receivables. Lazaridis and Tryfonidis (2007) analyzed Greek listed companies and found a negative and significant correlation between CCC and probability. Their research indicated that less profitable companies decrease DSO to minimize the cash gap in the CCC.

Enqvist et al. (2013) investigated the influence of working capital management (WCM) of Finnish listed companies over an 18-year period and found a negative relationship between cash WCM and profitability. Lastly, Bozzeda (2017) analyzed 117 non-financial Latin America companies from 2005 to 2015 and found a significant negative relationship between CCC and profitability (ROA).

\subsection{Working capital and profitability in the Brazilian pharmaceutical industry}

In Brazil, MNEs, that commercialized innovative, and patent protected drugs, dominated the pharmaceutical market, because of investments in R\&D and the discovery of new molecules (Torres et al, 2011). National companies (NACs) had a marginal participation in the market, given the high costs incurred when developing innovative drugs and the high risk associated with this process (Gomes, 2017). Because MNEs enjoyed such competitive advantages worries about working capital and profitability management were minor. In 1999, however, the creation of the Brazilian health regulatory agency (ANVISA), the institution of a "generic drugs" regulation and the establishment of the Medication regulation chamber (CMED) changed this scenario. ANVISA revisited the registration process for new drugs and prioritized registering medicines that could offer more health benefits to the population, while also incentivizing the market competition and reducing prices. Consequently, the registration of innovative products became a lengthy process, which influenced MNEs a competitive advantage. Similarly, setting a new product pricing became a challenge due to CMED strict regulations and pricing control, which limited the ability to increase profitability by increasing prices.

As a result, national companies received government support and started large investment programs aimed at producing generic and patent-free medication. The Brazilian Development Bank established a special program to fund pharmaceutical companies at subsided rates. In parallel, the MNEs begun suffering the pressure to replace its aging portfolios given the expiration of patents. Considering the uncertain, lengthy and costly process to launch a new molecule, MNEs changed their strategy: they reduced investments to minimize the R\&D uncertainty and integrated production operations globally, aiming to achieve cost efficiencies via a global supply chain strategy (Sousa et al, 2010). As a result, the Brazilian association of chemical companies (Abifina) estimated that MNEs deactivated more than one thousand manufacturing production sites (Filho and Pan, 2003) and started importing inputs from their headquarters and operating with higher levels of inventory, causing significant impacts on the Brazilian trade balance of pharmaceutical products. Besides, global pharmaceutical players went through a series of mergers and acquisitions, and in 2016 the top five companies dominated $47 \%$ of the total pharmaceutical retail market (Abrafarma, 2016) and the three biggest wholesalers achieved $34 \%$ of the total market revenues in 2017 (IQVIA). In this new scenario, efficient working capital management became a critical factor for both MNEs and NACs. Market concentration increased the importance of trade credit and commercial discounts as a commercial lever, and consequently the importance of accounts receivable and profitability management. While MNEs concentrated their efforts in liquidity management, NACs focused on the correct allocation of funds in capital investments (production plants) and inventory (raw material and inventory). Regardless of the business model, profit maximization became a constant challenge for industry players. The bargaining power of the Brazilian Ministry of Health in large-scale purchases is an additional pressuring factor for industry profitability. Moreover, price controls imposed by CMED represented a strategic barrier to MNEs, while NACs face the challenge of commercializing low-priced products with no technological differentiation. 
Trade terms are a particularly critical factor in the relationship between pharmaceuticals and customers because of the high concentration of the sales channel: the eight major players account for $80 \%$ of private pharmaceutical market sales. Accounts payable also differ between MNEs and NACs. MNEs usually work with a single supplier (headquarters) that enforces strict payment and negotiation policies that minimize shareholders risks that arise from international operations (Wihlborg, 1980).

\subsection{Asset and Liability of Foreignness in working capital}

\subsubsection{Accounts Receivable}

Accounts receivable are the funds the customers own to the company. A receivable is a line of credit extended by the company to its customer due in a short period. A company's commercial strategy, trade credit policy and collection efficiency are the main factors that determine its accounts receivable position. Trade credit can be a sales lever, because increasing the trade credit period is equivalent to a higher discount (Mian and Smith, 1992). Yet, the trade credit strategy depends on a company's competitive position and bargaining power. The pharmaceutical sector commercial environment is highly concentrated (IQVIA, 2017) and sustaining a healthy commercial relationship may be costly to some companies.

The literature has emphasized that MNEs bringing capital and technology enjoy a considerable advantage (assets of foreignness) over domestic entities (Sethi et al, 2009). When negotiating with distributors, MNEs have an advantage over NACs due to their high-margin products compared to generic drugs, which impacts their levels of trade credit investments and commercial discounts. Lee (2016) analyzed MNEs operating in the Brazilian electronics sector and concluded that they are more predisposed to use factoring strategies to reduce accounts receivable position, maintain a higher level of cash and, consequently, operate with a higher financial flexibility for investments and potential uncertainties in a foreign market.

Lazaridis et al, (2007) analyzed companies listed in Athens Stock Exchange and verified that companies with low DSO levels are less profitable and they use this strategy to reduce the cash gap in their working capital. Deloof (2003) and Gill (2010) analyzed large Belgian non-financial and American companies, respectively, and identified a negative relationship between the number of days in account receivables (DSO) and profitability.

Given these findings, we hypothesize that MNEs have lower DSO and higher profitability than NACs (H1), because MNEs have a competitive advantage over NACs, and thus need lower investments of trade terms to sustain commercial competitiveness and commercialize high-margin, innovative products.

\subsubsection{Inventories}

The relationship between inventory and sales determines inventory-holding decisions. Higher inventory levels often imply weaker demand levels, and higher levels of competition can lead to inefficient inventory management. Lazaridis et al (2006) and Enqvist et al. (2013) found a negative relationship between inventory levels and profitability. The analyzed companies achieved higher levels of profitability by increasing the efficiency of inventory management and minimizing the inventory conversion cycle.

MNEs manufacturing strategy relies on a single production site that supplies products to all subsidiaries. Therefore, besides managing the importation process of products, MNE subsidiaries must monitor trade policies and deliberations of multilateral agencies while dealing with deteriorated infrastructure, regulatory uncertainties and exchange rate volatility. Altogether, these factors represent additional costs for MNEs, therefore referred to as a form of liability of foreignness (LOF) (Zaheer and Mosakowski, 1997).

Costa (2017), identified that several regulations, such as certifications that must be in place for suppliers, manufacturing, logistics and distribution, are applied along the nodes of medical and pharmaceutical industries in Brazil and concluded that among the main mitigation strategies applied by these firms is the excess of inventory.

Given these findings, we hypothesize that MNEs operate with higher inventory levels to overcome the complexity and risks that exist along its supply chain network (H2). Higher inventory levels may be harmful to MNEs' margins. Therefore, we expect to find a negative relationship between inventory levels and profitability for MNEs.

\subsubsection{Accounts Payable}

Accounts payable are an outstanding obligation with suppliers. Higher accounts payable levels are helpful in settling commitments with vendors and indicate higher bargaining power (Brealey et al, 2013). Gill et al (2010) and Deloof (2003) identified a negative relationship between accounts payable and profitability, suggesting that the later a company pays the bills, the higher its profitability.

One effect from the integration of production operations globally is the fact that MNEs parent company became the subsidiary's primary supplier. This movement increased the MNE global network interdependency and consequently reduced the subsidiary management independence because it must cope with locally regulated payment policies established by headquarters. NACs, in contrast, have more flexibility to manage their payment schedules. The liability of 
foreignness (LOF) refers to the transaction costs faced by MNEs when purchasing from headquarters (Hymer (1960), Zaheer et. al (2009)). Brazilian Law 6.404/1976 regulates intercompany payment terms and determines that the payment terms to the parent company must be short; otherwise, the Brazilian Central Bank would classify it as an intercompany loan, which would implicate interests and taxes (PWC, 2016).

Given these findings, we hypothesize that MNEs exhibit a negative relationship between DPO and ROA (H3).

\subsubsection{Cash Conversion Cycle}

The cash conversion cycle (CCC) has three components: accounts receivable translation period, inventory conversion period and accounts payable deferral period. To optimize its CCC, a company can improve each of the three components independently. For example, it can delay payments to suppliers and increase-working capital efficiency. In this sense, the working capital efficiency does with accelerating cash collection and reducing cash disbursements. As a result, efficient companies have shorter CCCs by operating with lean stocks, collecting their receivables quickly and delaying payments to suppliers. Because MNEs must overcome the competitive disadvantage derived by importing inputs, they often operate with higher inventory levels than NACs, as well as with lower accounts payable deferral period to comply with its global network interdependency and host-country local laws. Deloof (2003), Lazaridis et al. (2007), Enqvist et al. (2013) and Bozzeda (2017) observed a significant and negative relationship between CCC and profitability.

Given these findings, we hypothesize that MNEs exhibit a positive relationship between CCC and profitability (H4).

\section{METHODS \& DATA}

\subsection{Literature research}

The purpose of this study is to analyze whether the AOF and LOF phenomenon prevails in the Brazilian pharmaceutical industry.

To search for references on the topic, we used Science Direct, J Stor, Scielo, Wiley, FGV Digital Repository and Google Scholar to search for the following terms: liability of foreignness, asset of foreignness, Brazilian pharmaceutical industry, working capital management, working capital management in pharma industry and supply chain in pharmaceutical industry. Filtering by author, title, keywords, economy sector, results, and conclusions. We selected forty-seven articles.

\subsection{Data selection}

Our initial sample includes the 2017 IQVIA Ranking, which includes 548 Brazilian pharmaceutical companies. We selected companies with total assets higher than $\mathrm{R} \$ 240$ million or gross annual revenue exceeding $\mathrm{R} \$ 300 \mathrm{million}$. The cutoff values are in accordance with the Brazilian Law 11.638/2007, which requires that all companies that meet these conditions publish their financial statements in the Official Gazette of the state in which the company's head office is located or in another major circulation newspaper. Second, we only considered companies whose ownership is exclusively national or international so that we could isolate the foreignness effect. We then used the State Official Gazettes and Valor Econômico Newspaper to gather data on thirty-one companies, 13 of which are MNEs. Some companies use legal injunctions to avoid releasing their financial information to the public. After that, we only selected companies that had available information for six consecutive fiscal years (2011 to 2016), which led to the exclusion of one MNE. Finally, we excluded the three smallest national companies (in terms of revenue). The final sample contains eleven companies from Brazil, three from Germany, two from France, two from Switzerland and one for Belgium, Denmark, Mexico, and the United States. Table 1 summarizes the origin of the companies included in the sample.

Table 1 - Home base of selected companies

\begin{tabular}{c|c|c}
\hline Parent country & $\mathbf{n}$ & $\mathbf{\%}$ \\
\hline Brazil & 11 & $50.0 \%$ \\
Germany & 3 & $13.6 \%$ \\
France & 2 & $9.1 \%$ \\
Switzerland & 2 & $9.1 \%$ \\
Belgium & 1 & $4.5 \%$ \\
Denmark & 1 & $4.5 \%$ \\
Mexico & 1 & $4.5 \%$ \\
United States & 1 & $4.5 \%$ \\
\hline Total & $\mathbf{2 2}$ & $\mathbf{1 0 0 \%}$ \\
\hline \multicolumn{2}{c|}{ Source: Elaborated by authors }
\end{tabular}




\subsection{Variables}

In accordance with Deloof (2003), Lazaridis et al (2006), Gill et al (2010), Enqvist et al (2014) and Bozzeda (2017), the dependent variable is the return on assets (ROA), measured as the ratio of net income to total assets. This measure reflects the company's overall profitability and is not affected by special items or by the company's capital structure (Barber and Lyon, 1996). The authors also use the following dependent variables: days of sales outstanding (DSO), days of inventory outstanding (DIO), days of payables outstanding (DPO) and cash conversion cycle (CCC).

DSO is a measure of the average number of days until the customer pays their bills. The higher the DSO the longer the cash cycle and therefore the higher working capital levels. DIO is a ratio measuring the average number of days an item is held in the inventory. A high DIO means a potential weak demand or inefficient inventory management. However, a lower inventory-holding period will indicate that the company investment in inventory is too low, high demand for the goods sold or efficient inventory management. DPO measures how long it takes a company to meet its outstanding payments. A higher DPO suggests a higher bargaining power with vendors. Finally, the longer the CCC, the greater the net investment in current assets, and hence the greater the need for financing current assets. The calculations for each of these variables follow Shin and Sonen (1998):

$$
\begin{gathered}
\text { DSO }=(\text { Accounts Receivables } / \text { Sales }) \times 365 \\
\text { DIO }=(\text { Inventory } / \text { Sales }) \times 365 \\
\text { DPO }=(\text { Accounts Payables } / \text { Sales }) \times 365 \\
\text { CCC }=(\text { DSO+DIO })-\text { DPO }
\end{gathered}
$$

As controls, we use Size (net sales), Leverage (Short-Term Loans + Long-Term Loans)/Total Assets) and Fixed Assets as a proportion of total assets. We measured Size according to Enqvist et al (2014) and Bozzeda (2017). The authors use this variable as an inverse proxy of financial constraints, suggesting that smaller companies face higher informational asymmetry and agency costs and, thus, are more financially constrained. For this reason, smaller companies tend to exhibit lower working capital levels than large companies. The leverage the (LEV) is based on Gill et al (2010), Enqvist et al (2014) and Bozzeda (2017). The authors suggest that the Financial Debt to Total Assets Ratio (Leverage) affects the relationship between profitability and working capital. Fixed assets (FA) measure follows Deloof (2003) and Gill et al (2010).

Additionally, we also test for a lagged return on assets $\left(\mathrm{ROA}_{\mathrm{t}-1}\right)$ because managers often pursue earnings smoothing (Lemmons et al, 2008).

The dummy variable $\lambda$ captures the ownership origin of the company (MNEs or NACs). This variable allows identification of the existence of AOF or LOF in pharmaceutical companies. 
Table 2 - Variables

\begin{tabular}{|c|c|c|c|c|c|}
\hline & Variable & Description & Scale & $\begin{array}{l}\text { Expected } \\
\text { Sign }\end{array}$ & Main Literature \\
\hline Dependent & Dependent & $\begin{array}{c}\text { ROA } \\
\text { (Return on Asset) }\end{array}$ & $\%$ & & \\
\hline $\begin{array}{c}\text { Main } \\
\text { Independent }\end{array}$ & $\lambda$ & The firm is foreign owned & $\begin{array}{l}\text { (0) national } \\
\text { (1) foreign }\end{array}$ & & \\
\hline \multirow{7}{*}{ Controls } & DSO & $\begin{array}{l}\text { Measure of the average } \\
\text { number of days until the } \\
\text { customer pays their bills }\end{array}$ & Days & - & $\begin{array}{c}\text { Deloof (2003) } \\
\text { Gill et al (2010) } \\
\text { Lazaridis et al (2006) } \\
\text { Bozzeda (2017) }\end{array}$ \\
\hline & DIO & $\begin{array}{l}\text { Ratio measuring the } \\
\text { average number of days } \\
\text { an item is held in the } \\
\text { inventory }\end{array}$ & Days & + & Bozzeda (2017)) \\
\hline & DPO & $\begin{array}{l}\text { Measure the average } \\
\text { period it takes a company } \\
\text { to meet its outstanding } \\
\text { payables }\end{array}$ & Days & - & $\begin{array}{c}\text { Deloof (2003) } \\
\text { Lazaridis et al (2006) } \\
\text { Enqvist et al (2014) }\end{array}$ \\
\hline & $\mathrm{CCC}$ & $\begin{array}{c}\text { Cash Conversion Cycle = } \\
(\mathrm{DSO}+\mathrm{DIO})-\mathrm{DPO}\end{array}$ & Days & + & $\begin{array}{c}\text { Deloof (2003) } \\
\text { Lazaridis et al (2006) } \\
\text { Enqvist et al (2014) } \\
\text { Bozzeda (2017) }\end{array}$ \\
\hline & SIZE & Net Sales & $\mathrm{R} \$ 000 \mathrm{~s}$ & + & $\begin{array}{l}\text { Deloof (2003), Enqvist et } \\
\text { al (2014), Bozzeda (2017) }\end{array}$ \\
\hline & FA & Fixed Assets/Total assets & $\%$ & - & Gill et al (2010) \\
\hline & LEV & $\begin{array}{c}\text { Financial Debt Ratio = } \\
\text { (Short-Term Loans }+ \\
\text { Long-Term Loans)/Total } \\
\text { Assets }\end{array}$ & $\%$ & - & $\begin{array}{l}\text { Gill et al (2010) } \\
\text { Enqvist et al (2014) } \\
\text { Bozzeda (2017) }\end{array}$ \\
\hline
\end{tabular}

Source: Elaborated by authors 


\subsection{Models}

Using panel data considering twenty-two different companies across six years and following Deloof (2003), Lazaridis et al (2006), Gill et al (2010), Enqvist et al (2014) and Bozzeda (2017), we use the following equations to test the proposed hypotheses (H1-H4):

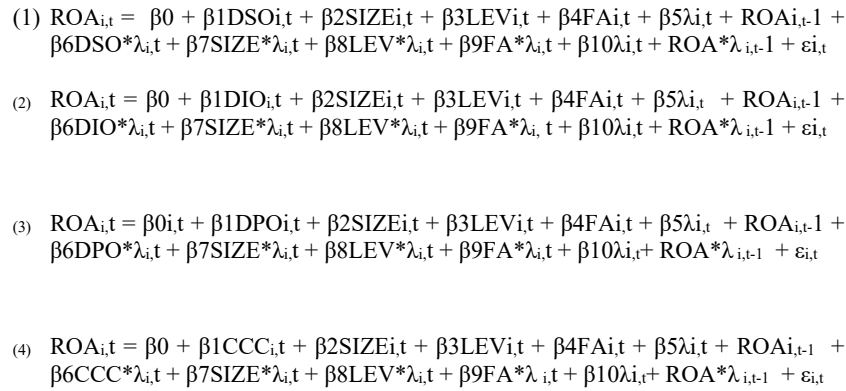

Where:

$\beta 0$ : Intercept of the equation

$\beta 1, \beta 2, \beta 3, \beta 4, \beta 5$ : Coefficients of variables

ROA: Return on Assets

DSO: Days of sales outstanding

DIO: Days of inventory outstanding

DPO: Days of payment outstanding

CCC: Cash conversion cycle

SIZE Net Sales

LEV: Financial Debt Ratio

FA: Fixed Assets to Total assets

ROAt-1: Return on assets lagged result variable

$\lambda$ : Multinational dummy

t: Time in years

$\varepsilon$ : The error term

\section{RESULTS}

The focus of our descriptive statistics is to evaluate the relationship between working capital management and the company's profitability. Using STATA version 15.1., we performed correlation analysis and estimated variance inflation factors (VIF) to detect multicollinearity. VIF values higher than five indicate a multicollinearity problem (Gujarati, 2003), but is not the case in our sample since all VIF was lower than 1.6. We then performed panel data regressions using fixed effects models (FEM) and random effects models (REM). We selected the best model according to the Hausman test. Results suggest that the most appropriate model is the FEM. Moreover, FEM is an appropriate specification for this study because it focuses on a specific set of eleven companies and the proposed inference is restricted to the behavior of this set of firms during a certain period. We also interacted the time-invariant variable (dummy $\lambda$ ) with regressors to show how the effect of a prediction variable (dummy $\lambda$ ) on the outcome may vary.

Finally, we performed heteroscedasticity tests (modified Wald tests) in the four main specifications. This is a concern in the regression analysis as it can invalidate statistical tests of significance because the standard errors of these estimates will be biased leading to a bias in test statistics and confidence intervals. Wald tests confirmed the existence of a heteroscedasticity problem. To correct for this, we used robust standard errors (Baltagi, 2005).

\subsection{Descriptive Statistics}

Table 3 provides descriptive statistics for all variables captured from twenty-two companies from the year of 2011 to 2016 (110 observations).

The lowest DSO value (39.7) refers to a NAC, while the highest refers to a MNE. The low value refers to NACs' preference to offering commercial discounts instead of trade terms when negotiating product sales with its customers. A high DSO value for a MNE, on the other hand, indicates that the company sells to the government, which may be delaying payments due to budgetary restrictions. On average, it takes 115.4 days for pharmaceutical companies in Brazil to collect their cash, with a standard deviation of 83.1 days. 
Regarding DIO, the lowest value is 26.2 days for a NAC, while the highest is 264.2 days for a MNE (the sample average is 80.5 days and standard deviation 40.2 days). This difference can be due to MNE's strategy to operate with higher product inventory levels. The intensive use of technology in manufacturing and automation could also explain these differences. For DPO, the minimum and maximum are 6.8 and 433.2 days, respectively, and the average is 66.0 days. Again, the lowest value refers to NAC and the highest refers to a MNE. The lowest value of NAC may be a consequence of a lower bargaining power with suppliers or a consequence of discounting for early payments to reduce supplier financing. The highest value for the MNEs must do with intercompany purchasing as a financing strategy, which is, the MNE delays its payment outstanding to HQ and allocate the funds to other obligations. However, from the head office perspective, this brings a major concern to financial managers about the risk these international transactions represent.

As per the CCC, some companies present a value of -40.4 , while others have a value of 406.3 days, and both refer to MNEs. On average, companies take 130 days to complete one full cash conversion cycle with a standard deviation of 68.6 days. Representatives from MNEs have both the most and least efficient working capital efficiency. Additional qualitative information would be useful to understand the drivers for such variability, such as internal management policies, years of experience operating in the foreign country or the degree of familiarity with the local market.

Regarding the value of return on assets (ROA), companies have an average $4 \%$ ROA, while the standard deviation is $24 \%$. MNEs exhibit maximum values (49.3\%) while NACs, the minimum values (-30\%). In terms of leverage, the higher ratio belongs to companies with aggressive financing policies. The ratio ranges from $0 \%$ to $96 \%$, with an average of $11 \%$ and a low standard deviation, probably because the companies in the sample follow similar financing policies. Sales range from 98.7 million BRL (a NAC) to 9.6 billion BRLs (a MNE). Fixed assets have a minimum of $0 \%$ and a maximum of $44 \%$, and both refer to NACs. Considering MNEs, the average FA was $13 \%$, while the average for NACs is $26 \%$. This difference suggests that NACs have higher investment in fixed assets, which reflects investments in equipment in local production sites.

Table 3 - Descriptive statistics for the variables

\begin{tabular}{c|c|c|c|c|c|c|c|c|c|c|c|c}
\hline Variable & \multicolumn{3}{|c|}{ Local Firms } & \multicolumn{3}{c}{ Foreign firms } & \multicolumn{3}{c}{ Total } \\
\hline & N & & & $\%$ & N & & & $\%$ & N & & \% \\
\hline $\begin{array}{c}\text { Total } \\
\text { Sample }\end{array}$ & 55 & & & 50 & 55 & & & 50 & 110 & & & 100 \\
\hline Numeric & Mean & Min & Max & SD & Mean & Min & Max & SD & Mean & Min & Max & SD \\
\hline ROA & $10 \%$ & $-30 \%$ & $31 \%$ & $11 \%$ & $-3 \%$ & $-111 \%$ & $49 \%$ & $32 \%$ & $4 \%$ & $-111 \%$ & $49 \%$ & $24 \%$ \\
DSO & 91,1 & 39,7 & 158,5 & 29,8 & 139,7 & 42,7 & 550,4 & 108,9 & 115,4 & 39,7 & 550,4 & 83,1 \\
DIO & 68,0 & 26,2 & 192,7 & 32,8 & 93,0 & 41,2 & 264,2 & 43,1 & 80,5 & 26,2 & 264,2 & 40,2 \\
DPO & 29,5 & 6,8 & 91,0 & 18,5 & 102,4 & 8,9 & 433,2 & 86,7 & 66,0 & 6,8 & 433,2 & 72,4 \\
CCC & 129,7 & 18,3 & 261,0 & 49,2 & 130,3 & $-40,4$ & 406,3 & 84,1 & 130,0 & $-40,4$ & 406,3 & 68,6 \\
SIZE & $1.197,8$ & 98,7 & $4.680,0$ & $1.197,8$ & $1.664,3$ & 31,6 & $9.621,0$ & $2.145,8$ & $1.431,1$ & 31,6 & $9.621,0$ & $1.745,5$ \\
FA & $26 \%$ & $5 \%$ & $44 \%$ & $10 \%$ & $13 \%$ & $0 \%$ & $28 \%$ & $8 \%$ & $19 \%$ & $0 \%$ & $44 \%$ & $11 \%$ \\
LEV & $14 \%$ & $0 \%$ & $43 \%$ & $10 \%$ & $8 \%$ & $0 \%$ & $96 \%$ & $17 \%$ & $11 \%$ & $0 \%$ & $96 \%$ & $14 \%$ \\
ROA t-1 & $10 \%$ & $-30 \%$ & $30 \%$ & $19 \%$ & $-4 \%$ & $-110 \%$ & $49 \%$ & $32 \%$ & $-2 \%$ & $-111 \%$ & $28 \%$ & $23 \%$ \\
\hline
\end{tabular}

Source: Elaborated by authors

\subsection{Correlation matrix}

Table 4 presents the Pearson correlation coefficients for all variables we used. There is a negative correlation between the Return on Assets (ROA) and the working capital components (inventories, accounts payables and cash conversion cycle). This finding is consistent with the research of Deloof (2003) and Lazaridis et al (2006). Correlation results indicate a negative coefficient between inventories and ROA (-0.6807), suggesting that if a company takes longer to sell its inventories, its profitability will decrease.

For accounts payable, there is a negative coefficient (-0.0364) between DPO and ROA. A rational explanation according to Deloof (2003) is that companies wait too long to pay their suppliers. An early payment to suppliers might increase the profitability of the company due to large discounts for punctual payments. We also observe a positive correlation (0.0364) between accounts receivables (DSO) and ROA. This means that if the number of days of AR increases, profitability also increases. An explanation to this result may be the fact that customers delay paying their obligations but include payment of penalties and interest when settling the payments. Besides, companies may offer trade terms instead of 
discounts on product prices. The cash conversion cycle and ROA have a negative correlation. This is consistent with the theory that the interval between the expenditure for the purchases of inputs and the collection of sales of finished goods can be too long, and a decreasing interval increases profitability (Deloof, 2003). We also observe a significant and positive correlation between sales and ROA. These findings suggest that as the size of the company increases, profitability also increases, in accordance with Deloof (2003), Lazaridis et al (2006) and Gill et al (2010), suggesting.

The results show that the financial debt ratio has a negative correlation $(-0.3609)$ with profitability, indicating that higher leverage is associated with a decrease in profitability. Finally, the correlation between fixed asset ratio (FA) and profitability is positive $(0.2324)$, which demonstrates that an increase in fixed assets is associated with an increase in profitability. This agrees with Deloof (2003) and Lazaridis et al (2006).

Table 4 - Correlation matrix of numerical variables

\begin{tabular}{|c|c|c|c|c|c|c|c|c|c|c|}
\hline Variable & ROA & ccc & DIO & DPO & DSO & SIZE & $\mathbf{A F}$ & LEV & $\begin{array}{c}\text { ROA } \\
\text { t-1 }\end{array}$ & DUMMY \\
\hline ROA & 1 & & & & & & & & & \\
\hline $\operatorname{ccc}$ & $-0,0928$ & 1 & & & & & & & & \\
\hline DIO & $-0,6807$ & $\begin{array}{c}0.3202 \\
\star \star *\end{array}$ & 1 & & & & & & & \\
\hline DPO & -0.2477 & $-0,0808$ & $\begin{array}{c}0.3585 \\
\star \star \star *\end{array}$ & 1 & & & & & & \\
\hline DSO & 0.0364 & 0.6000 & 0,0936 & 0,6315 & 1 & & & & & \\
\hline SIZE & $\underset{\star \star}{0.2128}$ & 0,3892 & $\begin{array}{c}-0.1929 \\
\star \star\end{array}$ & $-\frac{0.2093}{\star \star}$ & $\underset{\star \star}{0.2319}$ & 1 & & & & \\
\hline $\mathbf{A F}$ & $\underset{\star \star}{0.2324}$ & $-0,0222$ & $-0,0934$ & -0.1528 & -0.0697 & $-0,1995$ & 1 & & & \\
\hline LEV & -0.3609 & 0,1599 & $\underset{\star \star \star \star}{0.3416}$ & $-0,1359$ & -0.1515 & $-0,1165$ & 0,1251 & 1 & & \\
\hline ROA t-1 & 0,7956 & -0.0490 & $-0,6251$ & $-0,209$ & 0,0794 & 0,2104 & $\begin{array}{c}0.2720 \\
\star \star \star\end{array}$ & $\underset{\star}{-0.3310}$ & 1 & \\
\hline DUMMY & $-0,2718$ & 0,0043 & 0,3121 & 0,5029 & 0,2936 & 0,1342 & $-0,5952$ & $-0,2113$ & $-0,2821$ & 1 \\
\hline
\end{tabular}

Note: ${ }^{\star \star \star} \mathrm{p}<0.01,{ }^{\star \star} \mathrm{p}<0.05$ and ${ }^{*} \mathrm{p}<0.1$

Source: Elaborated by author

\subsection{Regression Analysis}

Tables 5 exhibit the regression results and Table 6 contrasts findings and hypotheses. Model (1) indicates that ROA and DSO are statistically insignificant suggesting that these variables cannot explain the impact of DSO on pharmaceutical companies' profitability (ROA), in contrast to Deloof (2003), Gill et al (2010), Lazaridis (2006) and Bozzeda (2017). This result holds for the coefficients of these variables when interacting with the MNE dummy. Therefore, there is no evidence to reject $\mathrm{H} 1$. Model (2) indicates a negative relationship between ROA and DIO (statistically significant at $5 \%$ level). This result indicates that high inventory levels are associated with a lower profitability, in contrast to Bozzeda (2017). When analyzing the coefficients of these variables with the interaction of the MNE dummy, the model is statistically significant at $1 \%$ level (negative relation). This result supports the second hypothesis ( $\mathrm{H} 2)$ and is in accordance with Deloof (2003) and Enqvist et al (2014).

Model (3) indicates that the relationship between ROA and DPO is not statistically significant, in contrast to Deloof (2003), Lazaridis et al (2006) and Enqvist et al (2014). The same finding holds when analyzing the interaction with the MNE dummy. This suggests that foreignness does not affect the relationship of AP and profitability and therefore there is no support for the third hypothesis (H3). Model (4) indicates that the relationship between CCC and ROA is not significant. There is no support for the fourth hypothesis (H4).

Company size (SIZE) is not significant in any of the specifications, suggesting that size does not affect the profitability of companies in the Brazilian pharmaceutical industry. The financial debt ratio (LEV) is negative and statistically significant at $1 \%$ level and, thus, is positively associated to profitability. For the interaction with the MNEs dummy, we observe a negative and significant relationship at 5\% level, in accordance with Deloof (2003), Gill et al (2010), Enqvist (2013) and Bozzeda (2017). The relationship between fixed asset ratio (FA) and ROA is not statistically significant, in 
contrast to Deloof (2003). For MNEs (when interacting with the MNE dummy), the results are similar.

Table 5 - Regression Results

\begin{tabular}{|c|c|c|c|c|c|c|c|c|c|c|c|c|}
\hline & \multicolumn{3}{|c|}{ Model 1} & \multicolumn{3}{|c|}{ Model 2} & \multicolumn{3}{|c|}{ Model 3} & \multicolumn{3}{|c|}{ Model 4} \\
\hline Variable & & Coefficient & Std Error & & Coefficient & Std Error & & Coefficient & Std Error & & Coefficient & Std Error \\
\hline DSO & M1 & $-0,0000772$ & 0,0005914 & & - & - & & - & - & & - & - \\
\hline DIO & & - & - & M2 & $\begin{array}{c}-0.0026402 \\
\star \star\end{array}$ & 0,0007663 & & - & - & & - & - \\
\hline DPO & & - & - & & - & - & M3 & $-0,0008707$ & 0,0005158 & & - & - \\
\hline $\mathrm{ccc}$ & & - & - & & - & - & & - & - & M4 & $-0,0005315$ & 0,0003968 \\
\hline SIZE & & 0.0000195 & 0.0000200 & & 0.0000112 & 0.0000170 & & -1.2400060 & 0,0000287 & & 0.0000213 & 0,0000189 \\
\hline FA & & -1.3551050 & 0,9440416 & & $-0,7396127$ & 0,6309659 & & -1.2320980 & 0,8557782 & & -1.1576830 & 0,8627496 \\
\hline LEV & & $\begin{array}{c}-0.1466243 \\
\star \star\end{array}$ & 0,0631552 & & $-0,0703556$ & 0.0634040 & & $\begin{array}{c}-0.1962755 \\
\star \star \star\end{array}$ & 0,0499401 & & $-0,0994642$ & 0,0753746 \\
\hline ROA t-1 & & 0.0308180 & 0,2371005 & & 0.0077638 & 0,2988738 & & 0.0809553 & 0,2947724 & & $-0,0116783$ & 0,2374368 \\
\hline $\mathrm{DSO} * \lambda$ & M1 & $-0,0011155$ & 0,0007031 & & - & - & & - & - & & - & - \\
\hline $\mathrm{DIO} * \lambda$ & & - & - & M2 & $\begin{array}{c}-0.0026874 \\
\star \star \star\end{array}$ & 0,0009506 & & - & - & & - & - \\
\hline $\mathrm{DPO} * \lambda$ & & - & - & & - & - & M3 & $-0,0010919$ & 0,0007947 & & - & - \\
\hline $\operatorname{ccc} \star \lambda$ & & - & - & & - & - & & - & - & M4 & $-0,0006657$ & 0,0004722 \\
\hline $\operatorname{SIZE} * \lambda$ & & 0.0000257 & 0,0000269 & & 5.9200070 & 0,0000221 & & -0.0000229 & 0,0000425 & & 0.0000311 & 0,0000302 \\
\hline $\mathbf{F A} * \lambda$ & & -2.1191710 & 1.2879720 & & -1.2680050 & 0,8943474 & & -2.1004680 & 1.2548250 & & -1.6552890 & 1.1877260 \\
\hline $\operatorname{LEV}^{*} \lambda$ & & -0.0653864 & 0,0546496 & & $-0,0273508$ & 0,0654674 & & $\begin{array}{c}-0.142285 \\
\star \star\end{array}$ & 0,0429627 & & -0.1779330 & 0.0535870 \\
\hline ROA t $-1 * \lambda$ & & 0.6901820 & 0,2777112 & & 0.0391278 & 0,3682738 & & 0.16343030 & 0,3812083 & & $-0,0063738$ & 0.3004410 \\
\hline Constant & & 0.2269835 & 0.1121000 & & 0.2390722 & 0,0977044 & & 0.24901870 & 0,0141595 & & 0.1553462 & 0,0820709 \\
\hline $\begin{array}{l}\text { Sample } \\
\text { size (n) }\end{array}$ & & 110 & & & 110 & & & 110 & & & 110 & \\
\hline R-Squared & & 0,0672 & & & 0,2418 & & & 0,1133 & & & 0,0892 & \\
\hline p-value & & 0.0000 & & & 0.0000 & & & 0.0000 & & & 0,0001 & \\
\hline
\end{tabular}

Note: ${ }^{\star \star \star} \mathrm{p}<0.01,{ }^{\star \star} \mathrm{p}<0.05$ and ${ }^{*} \mathrm{p}<0.1$

Source: Elaborated by authors 
Table 6 - Regression Analysis

\begin{tabular}{|c|c|c|c|c|c|c|c|c|}
\hline & \multicolumn{2}{|c|}{ Hypothesis 1} & \multicolumn{2}{|c|}{ Hypothesis 2} & \multicolumn{2}{|c|}{ Hypothesis 2} & \multicolumn{2}{|c|}{ Hypothesis 4} \\
\hline Variable & $\begin{array}{c}\text { Expected } \\
\text { Effect }\end{array}$ & $\begin{array}{c}\text { Actual } \\
\text { Effect }\end{array}$ & $\begin{array}{c}\text { Expected } \\
\text { Effect }\end{array}$ & $\begin{array}{c}\text { Actual } \\
\text { Effect }\end{array}$ & $\begin{array}{c}\text { Expected } \\
\text { Effect }\end{array}$ & $\begin{array}{c}\text { Actual } \\
\text { Effect }\end{array}$ & $\begin{array}{l}\text { Expected } \\
\text { Effect }\end{array}$ & $\begin{array}{c}\text { Actual } \\
\text { Effect }\end{array}$ \\
\hline DSO & - & ns & & & & & & \\
\hline DIO & & & + & $-* *$ & & & & \\
\hline DPO & & & & & - & ns & & \\
\hline $\operatorname{ccc}$ & & & & & & & + & ns \\
\hline SIZE & + & ns & + & $\mathrm{ns}$ & + & ns & + & ns \\
\hline FA & - & ns & - & ns & - & $\mathrm{ns}$ & - & ns \\
\hline LEV & - & 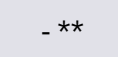 & - & ns & - & $-* \star *$ & - & ns \\
\hline DSO* $\lambda$ & - & ns & & & & & & \\
\hline $\mathrm{DIO} *_{\lambda}$ & & & - & $-* \star *$ & & & & \\
\hline $\mathrm{DPO}{ }_{\lambda}$ & & & & & - & ns & & \\
\hline $\operatorname{cCC}^{\star} \lambda$ & & & & & & & - & ns \\
\hline $\operatorname{SIZE}_{\lambda}{ }_{\lambda}$ & + & ns & + & ns & + & ns & + & ns \\
\hline $\mathbf{F A} *_{\lambda}$ & - & Ns & - & Ns & - & Ns & - & ns \\
\hline
\end{tabular}

Note: ns: not significant, ${ }^{\star \star \star} \mathrm{p}<0.01,{ }^{\star \star} \mathrm{p}<0.05$ and ${ }^{*} \mathrm{p}<0.1$

Source: Elaborated by authors

\section{CONCLUSION}

The purpose of this study was to analyze the existence of the asset or liability of foreignness phenomena in the Brazilian pharmaceutical industry. Our main hypothesis investigated the relationship between working capital and profitability. To accomplish this, we used yearly data from twenty-two companies, from 2011 to 2016 with an empirical strategy of fixed effects panel data. This study contributes to the literature by evaluating the impact of Liability of Foreignness on working capital and profitability in the pharmaceutical sector.

The results demonstrate that MNEs have a competitive disadvantage of inventory management compared to local companies. There is a negative and statistically significant relationship between DIO and profitability. This negative relationship, as demonstrated by our models, suggests that MNEs are inefficient in inventory management, resulting in higher DIO and lower profitability. In our sample, MNEs operated with ninety-three days while NACs operated with sixty-eight days. MNEs import their products and must deal with its supply chain related complexities such as regulations, deteriorated infrastructure, trade agreements and exchange rate volatility. To mitigate this complexity, MNEs operate with higher inventory levels. Therefore, MNEs suffer LOF on working capital and inventory management.

We did not find evidence in favor of asset or liability of foreignness when analyzing DSO, DPO and CCC. The models also indicate that there is no association between profitability and company size. Moreover, financial debt ratio is negatively and statistically significant, implying that less profitable companies rely on external funds to finance operations.

Some limitations of the study include the limited sample size and the limited time sample period. Future studies could consider alternative proxies to measure the existence of AOF/LOF such as ROE, Gross Profit, EBITDA, the psychic distance, the effect of government subsidies on NACs/MNEs performance, or even the effect on sales growth rates imposed by the time it takes ANVISA to approve a new medication. In addition, future studies could incorporate pharmaceutical companies from other countries in Latin America. Finally, one could evaluate the impact of additional factors on profitability, such as economic activity, exchange rates and credit volume. 


\section{REFERENCES}

Abrafarma (2016). Números Abrafarma. https://www.abrafarma.com.br/informações

Almazari, A. A. (2013). The relationship between working capital management and profitability: Evidence from Saudi cement companies. British Journal of Economics, Management \& Trade, 4(1), 146-157.

Almeida, J. R. D. (2010). Gestão do capital de giro, acesso a financiamentos e valor da empresa (Master dissertation, Escola de Administração de Empresas de São Paulo da Fundação Getulio Vargas).

Almeida, J. R. D., \& Eid Jr, W. (2014). Access to finance, working capital management and company value: Evidence from Brazilian companies listed on BM\&FBOVESPA. Journal of Business Research, 67(5), 924-934.

Anvisa (2017). Medicamentos prioridade para-registro. http://portal.anvisa.gov.br/rss/asset_publisher/Zk4q6UQCj9Pn/content/ medicamentos-prioridade-para-registro/21?Redirect=false

Avila, J. D. P. C. (2004). O desenvolvimento do setor farmacêutico: a caminho de uma estratégia centrada na inovação. Revista Brasileira de Inovação, 3(2), 283-307.

Baltagi, B. (2008). Econometric analysis of panel data. John Wiley \& Sons. $3^{\text {rd }}$.

Barber, B. M., \& Lyon, J. D. (1996). Detecting abnormal operating performance: The empirical power and specification of test statistics. Journal of financial Economics, 41(3), 359-399.

Barnard, H. (2010). Overcoming the liability of foreignness without strong firm capabilities-the value of market-based resources. Journal of International Management, 16(2), 165-176.

Bhattacharya, U., Galpin, N., \& Haslem, B. (2007). The home court advantage in international corporate litigation. The Journal of Law and Economics, 50(4), 625-660.

Blinder, A. S., \& Maccini, L. J. (1991). Taking stock: a critical assessment of recent research on inventories. Journal of Economic perspectives, 5(1), 73-96.

Bozzeda, R. (2017). The influence of working capital on corporate performance (Master dissertation, Escola de Economia de São Paulo da Fundação Getulio Vargas).

Brealey, R. A., Myers, S. C., Allen, F., \& Mohanty, P. (2013). Principles of corporate finance. Tata McGraw-Hill Education. $11^{\text {th }}$.

Caves, R. E. (1971). International corporations: The industrial economics of foreign investment. Economica, 38(149), 1-27.

Costa, V. B. (2017). The impact of regulatory policies on the supply chain resilience: regulation as supply chain resilience reducer in the medical and pharmaceutical supply chain in Brazil (Master dissertation, Escola de Administração de Empresas de São Paulo da Fundação Getulio Vargas).

Deloof, M. (2003). Does working capital management affect profitability of Belgian firms? Journal of business finance \& Accounting, 30(3-4), 573-588.

Delios, A., \& Beamish, P. W. (2001). Survival and profitability: The roles of experience and intangible assets in foreign subsidiary performance. Academy of Management journal, 44(5), 1028-1038.

Dunning, J. H., \& Lundan, S. M. (1998). The geographical sources of competitiveness of multinational enterprises: an econometric analysis. International Business Review, 7(2), 115-133.

Eden, L., \& Miller, S. R. (2004). Distance matters: Liability of foreignness, institutional distance and ownership strategy. In " Theories of the Multinational Enterprise: Diversity, Complexity and Relevance" (187-221). Emerald Group Publishing Limited.

Enqvist, J., Graham, M., \& Nikkinen, J. (2014). The impact of working capital management on firm profitability in different business cycles: Evidence from Finland. Research in International Business and Finance, 32, 36-49.

Fagre, N., \& Wells, L. T. (1982). Bargaining power of multinationals and host governments. Journal of International Business Studies, 13(2), 9-23.

Gaur, A. S., Kumar, V., \& Sarathy, R. (2011). Liability of foreignness and internationalization of emerging market firms. In "Dynamics of globalization: Location-specific advantages or liabilities of foreignness?" (211-233). Emerald Group Publishing Limited.

Gill, A., Biger, N., \& Mathur, N. (2010). The relationship between working capital management and profitability: Evidence from the United States. Business and economics journal, 10(1), 1-9.

Goguen, F. J., \& Connolly, J. D. (2012). Global wealth creation: The impacts on emerging markets' health care. http://www.thebostoncompany.com/assets/pdf/views-insights/Aug12_Global_Wealth_Creation_EMHealthCare.pdf

Gomes, R. D. P., Pimentel, V. P., Cardoso, M. L., \& Pieroni, J. P. (2014). O novo cenário de concorrência na indústria farmacêutica brasileira. BNDES Setorial, 39 (3), 97-134.

Gujarati, D. N., \& Porter, D. C. (2003). Basic Econometrics. $4^{\text {th }}$.

Hennart, J. F. (1982). A theory of multinational enterprise. University of Michigan Press

Hymer, S. (1983). The international operations of national firms: a study of direct investment: a dissertation from MIT (Doctoral dissertation, Massachusetts Institute of Technology).

Interfarma (2015). Comparações Internacionais no Comércio de Produtos Farmacêuticos e Balança Comercial Brasileira de Medicamentos. https://www.interfarma.org.br/public/files/biblioteca/70-balanaa-comercial-site.pdf 
IQVIA (2018) World Review Report 2017. https://www.iqvia.com/institute/reports

Kim, Y. H., \& Atkins, J. C. (1978). Evaluating investments in accounts receivable: A wealth maximizing framework. The Journal of Finance, 33(2), 403-412.

Lazaridis, I., \& Tryfonidis, D. (2006). Relationship between working capital management and profitability of listed companies in the Athens stock exchange. Journal of Financial Management and Analysis, 19 (1).

Lee, S. E. (2016). Gestão de capital de giro na internacionalização das empresas: uma análise comparativa entre empresas locais e multinacionais (Master dissertation, Escola de Administração de Empresas de São Paulo da Fundação Getulio Vargas).

Lemmon, M. L., Roberts, M. R., \& Zender, J. F. (2008). Back to the beginning: persistence and the cross-section of corporate capital structure. The Journal of Finance, 63(4), 1575-1608.

Mallon, M. R., \& Fainshmidt, S. (2017). Assets of foreignness: A theoretical integration and agenda for future research. Journal of International Management, 23(1), 43-55.

Meltzer, A. H. (1960). Mercantile credit, monetary policy, and size of firms. The Review of Economics and Statistics, $429-437$.

Mezias, J. M. (2002). Identifying liabilities of foreignness and strategies to minimize their effects: The case of labor lawsuit judgments in the United States. Strategic Management Journal, 23(3), 229-244. $169-200$

Mian, S. L., \& Smith Jr, C. W. (1992). Accounts receivable management policy: theory and evidence. The Journal of Finance, 47(1),

Miguel, P. L. D. S., \& Reis, M. D. A. (2014). Coordination in Brazilian pharmaceutical supply chains. Journal of Operations and Supply Chain Management, 7 (2), 75 - 90

Petersen, M. A., \& Rajan, R. G. (1995). The effect of credit market competition on lending relationships. The Quarterly Journal of Economics, 110(2), 407-443.

Raheman, A., \& Nasr, M. (2007). Working capital management and profitability-case of Pakistani firms. International review of business research papers, 3(1), 279-300.

Reis, C., Landim, A. B., \& Pieroni, J. P. (2011). Lições da experiência internacional e propostas para incorporação da rota biotecnológica na indústria farmacêutica brasileira. BNDES Setorial, 34(9), 5-44.

Sethi, D., \& Guisinger, S. (2002). Liability of foreignness to competitive advantage: How multinational enterprises cope with the international business environment. Journal of International Management, 8(3), 223-240.

Sethi, D., \& Judge, W. (2009). Reappraising liabilities of foreignness within an integrated perspective of the costs and benefits of doing business abroad. International Business Review, 18(4), 404-416.

Shin, H. H., \& Soenen, L. (1998). Efficiency of working capital management and corporate profitability. Financial practice and education, 8, 37-45.

Sousa, R. T., Liu, S., Papageorgiou, L. G., \& Shah, N. (2011). Global supply chain planning for pharmaceuticals. Journal of chemical engineering research and design, 89(11), 2396-2409.

Torres, R. P., \& Souza, M. A. F. D. (2011). A dinâmica do mercado farmacêutico brasileiro segundo o modelo das estratégias genéricas de Porter. Sociedade, Contabilidade e Gestão, 5(3).

Vieira, F. S., \& Zucchi, P. (2006). Diferenças de preços entre medicamentos genéricos e de referência no Brasil. Revista de Saúde Pública, 40, 444-449.

Wihlborg, C. (1980). Economics of exposure management of foreign subsidiaries of multinational corporations. Journal of International Business Studies, 11(3), 9-18.

Zaheer, S. (1995). Overcoming the liability of foreignness. Academy of Management journal, 38(2), $341-363$.

Zaheer, S., \& Mosakowski, E. (1997). The dynamics of the liability of foreignness: A global study of survival in financial services. Strategic management journal, 18(6), 439-463. 